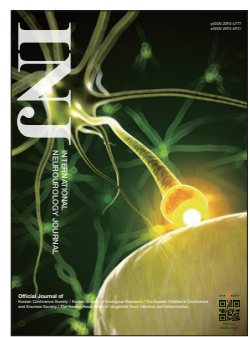

\title{
Particulate Matter (Fine Particle) and Urologic Diseases
}

\author{
Eun-A Kim \\ Occupational Safety and Health Research Institute, Korea Occupational Safety and Health Agency, Ulsan, Korea
}

\begin{abstract}
Particulate matter (PM) has been found to damage vital body organs, including the lungs and heart, through vascular damage and oxidative stress. Recently, renal function and chronic urologic diseases have also been found to be related to PM. To investigate this, we reviewed the characteristics of PM related to renal toxicity, including recent studies on the associations of urologic diseases with PM. PM can include constituents that cause renal toxicity, such as lead, cadmium, arsenic, and crystalline silica, which result in renal tubular or interstitial damage. Since 2008, 7 studies have evaluated the renal effects of PM. Two prospective cohort studies and a quantitative study of consecutive patients showed that PM may be related to decreased renal function, as shown by the estimated glomerular filtration rate of diseased or aged participants. Two cross-sectional studies found an association between PM and chronic kidney disease. One of those studies identified the specific renal diseases of immunoglobulin A nephropathy and membranous nephropathy. Two studies that analyzed renal cancer and PM showed no evidence that renal cancer is related to PM. Nine studies were evaluated regarding the relationship of bladder and prostate cancer with PM. The evidence for an association of PM with bladder and prostate cancer is still inconclusive. Although some recently published studies have shown a significant relationship, the causal relationship is not clear. Further well-designed studies on specific renal diseases are required.
\end{abstract}

Keywords: Particulate Matter; Fine Particle; Urologic Diseases; Occupational Diseases; Environmental Exposure

- Conflict of Interest: No potential conflicts of interest relevant to this article are reported.

\section{INTRODUCTION}

Particulate matter (PM) has been known to be an important cause of occupational and environmental disorders since the Great Smog of London [1,2], when PM levels were $\sim 3,000 \mu \mathrm{g} / \mathrm{m}^{3}$ (December 1952), resulting in high cardiopulmonary mortality. Since then, numerous studies regarding PM and human health have revealed that the cardiopulmonary system is particularly vulnerable to PM exposure [3-5]. Recently, the International Agency of Research on Cancer listed PM as a cause of lung cancer, based on studies showing that relatively low concentrations of PM had long-term effects on human health [6].
Since 2012, PM has increased in Korea, resulting in frequent episodes of poor air quality and increased public concern. Several studies have investigated the health consequences of this phenomenon, including ischemic heart disease, asthma, and hospital visits for Ménière disease related to PM [7-11].

The urinary system is frequently affected by occupational and environmental disorders, including acute and chronic renal failure, glomerulonephritis, tubular or interstitial nephritis, toxic nephropathy, and kidney and urinary bladder cancer due to exposure to heavy metals, organic compounds, and ionizing radiation [12-14]. Previous studies have established the toxicity of specific agents on the kidneys and/or urinary bladder. However,

Corresponding author: Eun-A Kim (iD https://orcid.org/0000-0002-8582-234X Occupational Safety and Health Research Institute, Korea Occupational Safety and Health Agency, 400 Jongga-ro, Jung-gu, Ulsan 44429, Korea E-mail: toxneuro@gmail.com / Tel: +82-52-703-0870 / Fax: +82-52-703-0870 Submitted: August 7, 2017 / Accepted after revision: September 8, 2017 
little research has been conducted on the effect of PM size [15-26].

The underlying mechanisms of how PM causes or exacerbates cardiopulmonary disorders are not yet fully understood. The major theories supported by scientific evidence are inflammation or oxidative stress in the microenvironment, and vascular endothelial damage by PM $[17,27]$. These cardiovascular alterations might affect the kidney, because it is a highly vascularized, multifunctional organ of the human circulatory system.

The susceptibility of the kidneys to environmental toxins can be explained by 4 factors: high blood flow, the ability of the kidney to concentrate toxic agents, the high metabolic activity of tubular cells, and the capacity of the kidney to dissociate protein-bound substances and to alter the $\mathrm{pH}$ of tubular fluid [12]. However, these 4 factors contributing to the susceptibility of the kidney have only been explained from a toxicological viewpoint, and the effect of particle size has not yet been considered.

According to the aerodynamic diameter, 2 categories of particles are regulated by the Environmental Protection Agency: coarse particulate matter $\left(\mathrm{PM}_{10}\right)$ with an aerodynamic diameter of $<10 \mu \mathrm{m}$, and fine particulate matter $\left(\mathrm{PM}_{2.5}\right)$ with an aerodynamic diameter of $<2.5 \mu \mathrm{m}$ [28]. Particles $<10 \mu \mathrm{m}$ in diameter can penetrate the nasal cavity to reach the alveoli, thus reaching the lungs and escaping into the blood stream. The smaller a particle is, the longer it will stay in the deeper sites of the lungs; furthermore, particles $<1 \mu \mathrm{m}$ act like gas molecules and reach the circulatory system [29]. If a small particle transitions into the vascular system, the kidneys theoretically become a direct target of PM. Recent epidemiologic studies have shown that $\mathrm{PM}_{2.5}[17,18]$ affected the decline of renal function and increased membranous nephropathy, meaning that the kidney is potentially susceptible to $\mathrm{PM}_{2.5}$. Although some studies have reported a relationship between PM and bladder and prostate cancer, the pathophysiology has not been proposed. Because most PM contains metals, gases, and various organic chemicals [30], the effects of PM should be considered both in terms of the toxicity of its components and the size of PM. Due to the tremendous renal capacity to compensate for functional loss, an early diagnosis of renal disease is difficult. For this reason, many studies have been done on end-stage renal disease to elucidate the effects of air pollution [31].

In this study, we reviewed the effect of PM on urologic disorders based on recent research in view of PM particle size and its constituents.

\section{PARTICULATE MATTER}

The term PM refers to a mixture of solid particles and liquid droplets in the air [32]. Both $\mathrm{PM}_{10}$ and $\mathrm{PM}_{2.5}$ are composed of inhalable particles of many sizes and shapes that contain hundreds of chemicals that react with each other. The main sources of PM are construction, unpaved roads, smokestacks and fires, power plants, the tire industry, and automobiles [32,33]. Naturally occurring PM comes from volcanoes, dust storms, forest fires, sea spray, and living vegetation [5].

The common chemical constituents of PM include inorganic ions (sulfates, nitrates, ammonium, sodium, calcium, and chloride), metals (cadmium, copper, nickel, vanadium, and zinc), polycyclic aromatic hydrocarbons, and microbial components. A major source of PM is traffic, due to brakes, tires, road dust, and pavement abrasion [34]. Indoor activities and sources, such as cooking, pets, carpet, aerosol cans, and office equipment, also generate PM [35].

As it is composed of particles $<10 \mu \mathrm{m}$ in diameter, $\mathrm{PM}_{10}$ has the greatest effect on human health. PM with a diameter of between 5 and $10 \mu \mathrm{m}$ is more likely to be deposited in the tracheobronchial tree, whereas PM between 1 and $5 \mu \mathrm{m}$ can move down to the respiratory bronchioles and alveoli. $\mathrm{PM}<1 \mu \mathrm{m}$ in diameter can penetrate the alveoli, and can translocate into cellular tissues and the circulatory system [5].

The pathophysiology of PM toxicity in the human body is not fully understood. One hypothesis is that the mechanism involves metal-mediated processes. Metal contained in particles can mediate airway inflammation due to PM. When transitional metals are involved in this process, reactive oxygen species can be generated [36]. Several studies have reported that the elemental components of PM are associated with cell membrane disruption, a strong potential to induce proinflammatory cytokines, and tumor necrosis factor $\alpha$-induced or mitochondriainduced apoptosis [37].

\section{TOXICITY OF PARTICULATE MATTER CONSTITUENTS ON THE KIDNEY}

The pathophysiology of PM depends on the size and toxicological properties of its constituents. Lead, cadmium, and arsenic are among the most common constituents of PM, and considerable research has been conducted on the renal effects of these metals [38]. All these metals can cause proximal tubular or interstitial damage and result in albuminuria or proteinuria. The 
available experimental evidence indicates that reactive oxygen metabolites, which can generate intermediate metals, cause glomerular disease and tubulointerstitial damage [39]. Another environmental risk to the kidneys is crystalline silica, which is known to be related to chronic renal failure. Although the toxic effect of crystalline silica on the kidneys is not yet understood, many studies have investigated chronic kidney disease in exposed populations [40].

It is well-known that environmental lead exposure leads to renal insufficiency, resulting in the major health problems of blood pressure and renal function damage. The environmental sources of lead are the lead-based paint used in the past and leaded gasoline. The kidneys are critically affected by long-term lead exposure. Acute lead nephropathy is characterized by the tubular transport mechanism (Fancoy syndrome), which shows tubular epithelium degeneration. Chronic exposure to lead can result in tubulointerstitial changes or chronic renal failure [41].

Cadmium is another important metal related to chronic kidney disease, and is produced by fuel combustion, household waste, tobacco smoke, and sewage. Cadmium exposure induces the synthesis of metallothionein, which is a cadmium scavenger in the liver. Cadmium-induced renal damage presents as proximal tubular dysfunction, hypercalcemia, and renal stones [38].

Arsenic exposure occurs from drinking water and food in the general population, and via inhalation when the exposure is occupational [42]. Although many constituents of PM affect the renal system, no single component cannot adequately explain the overall health effect observed in epidemiologic studies, due to the scarcity of data [43]. Although studies of arsenicinduced renal disease are rare, they have generally reported a positive association of arsenic with albuminuria and proteinuria in exposed populations; some studies showed a dose-response relationship [43].

Crystalline silica dust has been studied in the context of several occupational and environmental disorders, such as lung cancer, scleroderma, systemic lupus erythematosus, rheumatoid arthritis, or antineutrophil cytoplasmic antibody-associated vasculitis. Möhner et al. [40] conducted a meta-analysis exploring the association between respirable crystalline silica and nonmalignant renal disease. A total of 23 cohort and 4 casecontrol studies were included in the analysis. The authors found that the cohorts exposed to silica exhibited an elevated standardized mortality ratio (SMR), without a dose-response relationship. Cohorts with silicosis showed an overall SMR of 1.28 (95\% confidence interval [CI], 1.01-1.62). The combined anal- ysis of the industry-based cohorts resulted in an SMR of 1.52 (95\% CI, 1.16-1.98). Because the dose-response analysis was heterogeneous in these cohorts, the authors concluded that there were diagnostic and methodological issues related to the elevated SMR.

\section{PARTICULATE MATTER AND RENAL FUNCTION}

Previous studies on PM exposure and the circulatory system have identified renal function as an early index of cardiovascular disorders due to PM. Two prospective cohort studies and a quantitative study of consecutive patients have investigated whether decreased renal function is associated with PM exposure. The outcomes were albuminuria, microalbuminuria, and the estimated glomerular filtration rate (eGFR).

O’Neill et al. [15] conducted a prospective cohort study as part of their multiethnic study of atherosclerotic populations to investigate urinary albumin as a subclinical marker of microvascular function affected by PM (Table 1 ). The cohort consisted of 6,814 men and women aged 44-84 years who were free of clinical cardiovascular disease at baseline. Half of the study subjects were women, and their average age was 63 years old. The outcome of interest was creatinine-adjusted urinary albumin excretion. Subjects were classified into 4 categories of urine albumin excretion: normal, high-normal, microalbuminuria, and macroalbuminuria. Recent air pollution was assessed based on the participant's place of residence at the time of the baseline examination. Chronic exposure was estimated based on the residential history of each participant. Long-term exposure was estimated for $\mathrm{PM}_{10}$ and $\mathrm{PM}_{2.5}$ using direct measurements by an Environmental Protection Agency monitoring network. The estimated association between air pollution and creatinine-adjusted urinary albumin was mostly negative. There was only weak evidence that long-term exposure was associated with changes in microalbuminuria over time. The authors concluded that urinary albumin is not a marker for the mechanism underlying the association between the cardiovascular system and air pollution. Even if albumin levels are known to be well-correlated with microvascular dysfunction, the renal system is capable enough to compensate effectively in the healthy population.

Lue et al. [16] analyzed the eGFR of acute ischemic stroke patients to elucidate the effects of PM. The authors hypothesized that the eGFR would be associated with proximity to the major roads where PM is produced, because most PM-related health outcomes are vascular diseases and due to the profound 
Table 1. Summary of studies on the effects of particulate matter on the kidneys

\begin{tabular}{|c|c|c|c|}
\hline Study & Method & Subjects & Main result \\
\hline $\begin{array}{l}\text { O’Neill et al. } \\
\text { (2008) [15] }\end{array}$ & Prospective cohort & $\begin{array}{l}\text { 6,814 Men and women aged } 44-84 \text { years who } \\
\text { were free of clinical cardiovascular disease at } \\
\text { baseline }\end{array}$ & $\begin{array}{l}\text { Chronic and recent PM were not associated } \\
\text { with current urinary albumin or } \\
\text { microalbuminuria }\end{array}$ \\
\hline $\begin{array}{l}\text { Lue et al. } \\
\text { (2013) [16] }\end{array}$ & $\begin{array}{l}\text { Quantitative study of } \\
\text { consecutive patients }\end{array}$ & $\begin{array}{l}\text { Confirmed acute ischemic stroke patients } \\
\text { aged } \geq 21 \text { years, residing in the Boston } \\
\text { (MA, USA) metropolitan region } \\
\text { between } 1999 \text { and } 2004\end{array}$ & $\begin{array}{l}\text { Exposure associated with living near a major } \\
\text { roadway contributed to reduced renal } \\
\text { function (via the estimated glomerular } \\
\text { filtration rate) }\end{array}$ \\
\hline $\begin{array}{l}\text { Mehta et al. } \\
\text { (2016) [17] }\end{array}$ & Prospective cohort & $\begin{array}{l}\text { 2,280 Male volunteers from the greater } \\
\text { Boston area aged } 21-80 \text { years }\end{array}$ & $\begin{array}{l}\text { Long-term } \mathrm{PM}_{2.5} \text { exposure negatively } \\
\text { affected renal function and increased renal } \\
\text { function decline (via the estimated } \\
\text { glomerular filtration rate) }\end{array}$ \\
\hline $\begin{array}{l}\text { Xu et al. } \\
\text { (2016) [18] }\end{array}$ & Cross-sectional study & $\begin{array}{l}\text { Renal biopsy series including } 71,151 \text { native } \\
\text { biopsies at } 938 \text { hospitals spanning } 282 \text { cities } \\
\text { in China between } 2004 \text { and } 2014\end{array}$ & $\begin{array}{l}\text { Long-term exposure to high levels of } \mathrm{PM}_{2.5} \\
\text { was associated with an increased risk of } \\
\text { membranous nephropathy. }\end{array}$ \\
\hline $\begin{array}{l}\text { Yang et al. } \\
\text { (2017) [19] }\end{array}$ & $\begin{array}{l}\text { Cross-sectional } \\
\text { population-based study }\end{array}$ & $\begin{array}{l}21,656 \text { Adults evaluated between } 2007 \text { and } \\
2009 \text { in New Taipei City who were } \\
\text { participating in the Health Screening } \\
\text { Program }\end{array}$ & $\begin{array}{l}\text { Exposure during the previous year to } \mathrm{PM}_{10} \\
\text { and PMCoarse, but not } \mathrm{PM}_{2.5} \text {, was } \\
\text { associated with reduced renal function and } \\
\text { chronic kidney disease. }\end{array}$ \\
\hline $\begin{array}{l}\text { Raaschou-Nielsen et al. } \\
\text { (2011) [21] }\end{array}$ & Retrospective cohort study & $\begin{array}{l}\text { 54,304 Participants in the Danish Diet Cancer } \\
\text { and Health cohort }\end{array}$ & $\begin{array}{l}\text { Nitrogen oxides were weakly associated with } \\
\text { kidney cancer, without statistical significance. }\end{array}$ \\
\hline $\begin{array}{l}\text { Raaschou-Nielsen et al. } \\
\text { (2017) [20] }\end{array}$ & Retrospective cohort study & $\begin{array}{l}\text { European Study of Cohorts for Air Pollution } \\
\text { Effects included } 14 \text { cohorts of } 289,002 \\
\text { participants, with at least } 20 \text { incident kidney } \\
\text { parenchyma cancer cases during follow-up. }\end{array}$ & $\begin{array}{l}\text { An increased risk of kidney cancer was } \\
\text { associated with PM, although not to a } \\
\text { statistically significant extent. }\end{array}$ \\
\hline
\end{tabular}

PM, particulate matter.

vascularity of the kidney. The study population consisted of consecutive patients aged $\geq 21$ years with a confirmed history of acute ischemic stroke. The results showed that living near a major roadway was associated with a lower eGFR. Patients living within $50 \mathrm{~m}$ of a major road had a $3.9 \mathrm{~mL} / \mathrm{min} / 1.73 \mathrm{~m}^{2}$ lower eGFR (95\% CI, 1.0-6.7; P = 0.007) than those living within 1,000 $\mathrm{m}$ of a major road, and this result was not confounded or mediated by age, sex, race, history of hypertension, diabetes, or socioeconomic status. The authors explained that long-term exposure to traffic pollution leads to vascular endothelial injuries, systemic inflammation, atherosclerosis, and microvascular changes, which result in renal functional changes (Table 1).

Mehta et al. [17] concluded that $\mathrm{PM}_{2.5}$ reduced renal function in their Veterans Administration Normative Aging Study. The study included a closed cohort of 2,280 male volunteers from the greater Boston (MA, USA) area who were $21-80$ years old at study entry. The mean age of the participants was 73.5 years, and the majority were ex-smokers and used antihypertensive medications. One-year $\mathrm{PM}_{2.5}$ exposure was associated with a lower eGFR; more specifically, a $2.1 \mu \mathrm{g} / \mathrm{m}^{3}$ interquartile range higher 1-year $\mathrm{PM}_{2.5}$ exposure was associated with a 1.87 $\mathrm{mL} / \mathrm{min} / 1.73 \mathrm{~m}^{2}$ lower eGFR (95\% CI, -2.99 to -0.76 ]. Notably, participants using angiotensin receptor blockers showed a null association, implying that angiotensin receptor blockers might minimize the vasoconstrictive effect of PM.

The subjects analyzed by O'Neill et al. [15] were healthy, which might explain why they could not demonstrate a relationship between PM and albuminuria. By contrast, Lue et al. [16] included patients with acute ischemic stroke, and Mehta et al. [17] investigated an aged population who may have had agerelated renal function changes. From these findings, the glomerular filtration rate was shown to be a possible index for measuring early renal functional changes in unhealthy, vulnerable populations who are more sensitive to the effects of PM.

\section{CHRONIC KIDNEY DISEASE AND PARTICULATE MATTER}

Two studies analyzed PM-related chronic kidney disease. One of them identified the specific renal diseases of immunoglobu- 
lin A nephropathy and membranous nephropathy.

$\mathrm{Xu}$ et al. [18] collected 71,151 renal biopsy series over 11 years to investigate the temporal change of glomerular diseases associated with $\mathrm{PM}_{2.5}$. The authors found that immunoglobulin A nephropathy was the most common type of glomerulopathy (28.1\%), followed by membranous nephropathy (23.4\%). After adjustment for age and region, the odds of membranous nephropathy increased by $13 \%$ during the 11 years of the study. An increase of $10 \mu \mathrm{g} / \mathrm{m}^{3}$ in the $\mathrm{PM}_{2.5}$ concentration was associated with $14 \%$ higher odds for membranous nephropathy.

Yang et al. [19] recruited 21,656 adult participants with a mean age of 53.65 years during their 2007-2009 Health Screening Program. They calculated the eGFR using the Taiwanese Chronic Kidney Disease Epidemiology Collaboration equation. Exposure was estimated via annual average concentrations of $\mathrm{PM}_{2.5}, \mathrm{PM}_{10}$, and $\mathrm{PMCoarse}$ (defined as $\mathrm{PM}_{10}-\mathrm{PM}_{2.5}$ ) at each participant's residential address. The results showed that exposure during the previous year to $\mathrm{PM}_{10}$ and PMCoarse, but not $\mathrm{PM}_{2.5}$, was associated with the prevalence of chronic kidney disease and reduced renal function among Taiwanese adults. The association between PM and chronic kidney disease was stronger in females than in males for $\mathrm{PM}_{10}$. The authors noted that a possible reason for the null association of $\mathrm{PM}_{2.5}$ might be the different constituents and toxicity of PM according to diameter.

\section{RENAL CANCER AND PARTICULATE MATTER}

Almost all results showing renal cancer to be associated with environmental exposure have demonstrated a weakly increased risk related to gasoline vapors, engine exhaust, trichloroethylene, asbestos, and polycyclic aromatic hydrocarbons [44]. However, few studies have investigated PM exposure and renal cancer.

Raaschou-Nielsen et al. [21] explored the associations between traffic pollution and cancer incidence in a Danish cohort. In total, 57,053 men (48\%) and women (52\%) aged 50-64 years were recruited. The authors analyzed various cancers and components of air pollution. The incidence rate of kidney cancer was found to be weakly associated with nitrogen oxides, without statistical significance.

Using the European Study of Cohorts for Air Pollution Effects, Raaschou-Nielsen et al. [20] performed a multicenter cohort study to investigate the association between PM in outdoor air and kidney cancer. The participants were 14 cohorts located in 10 areas in Europe. In total, 289,002 participants were enrolled for the pooled analysis. Higher hazard ratios (HRs) were associated with higher PM concentrations (HR, 1.57; 95\% CI, $0.81-3.01$ per $5 \mu \mathrm{g} / \mathrm{m}^{3}$ of $\mathrm{PM}_{2.5}$ ), although the findings were not statistically significant. The authors concluded that the small number of kidney cancer cases and misclassification of the exposure might have resulted in statistical insignificance.

\section{BLADDER CANCER}

Studies on bladder cancer and PM have only recently been conducted, meaning that insufficient evidence is available to draw conclusions on the causal relationship.

Two case-control studies, 1 ecologic study, and 3 populationbased cohort studies have been conducted on the association between bladder cancer and PM (Table 2). All the results, except for 1 cohort study, showed a positive association.

Yanagi et al. [45] analyzed the association between $\mathrm{PM}_{10}$ and cancer incidence and mortality. They found that the incidence of some types of cancer, including bladder cancer, showed a statistically significant correlation with $\mathrm{PM}_{10}$.

Case-control studies conducted by Castaño-Vinyals et al. [46] and Liu et al. [47] showed a small to moderate positive association between several indices of air pollution and bladder cancer. In the results of Castano-Vinyals et al. [46], living more than 40 years in a large city was associated with bladder cancer (odds ratio [OR], 1.30; 95\% CI, 1.04-1.63). Polycyclic aromatic hydrocarbons and diesel were associated with an increased risk (OR, 1.29; 95\% CI, 0.85-1.98). Liu et al. [47] found a significant association between levels of air pollution and bladder cancer mortality (OR, 1.37; 95\% CI, 1.03-1.82).

The cohort studies reported uncertain correlations between bladder cancer and PM. Smith et al. [48] and Yeh et al. [22] found a positive association of air pollution and $\mathrm{PM}_{2.5}$ with bladder cancer. However, Pedersen et al. [23] did not find any such association in their study that included 15 populationbased cohorts.

\section{PROSTATE DISEASE}

Although studies on whether prostate cancer is related to PM exposure began earlier than studies of other urologic disorders, the evidence is still equivocal.

The association between prostate cancer and air pollution has been studied since Winkelstein and Kantor [24] analyzed the association of prostate cancer and air pollution in Erie County and Nashville. Because the study was conducted using 
Table 2. Summary of studies on the association between particulate matter and bladder cancer

\begin{tabular}{|c|c|c|c|}
\hline Study & Method & Subjects & Main result \\
\hline $\begin{array}{l}\text { Castaño-Vinyals et al. } \\
\text { (2008) [46] }\end{array}$ & Case-control study & 1,219 Incident cases and 1,271 hospital controls & $\begin{array}{l}\text { Living more than } 40 \text { years in a large city was } \\
\text { associated with bladder cancer (OR, 1.30; } 95 \% \\
\text { CI, 1.04-1.63). } \\
\text { Polycyclic aromatic hydrocarbons and diesel were } \\
\text { associated with an increased risk (OR, 1.29; } 95 \% \\
\text { CI, } 0.85-1.98 \text { ) }\end{array}$ \\
\hline $\begin{array}{l}\text { Liu et al. } \\
\text { (2009) [47] }\end{array}$ & $\begin{array}{l}\text { Matched } \\
\text { case-control study }\end{array}$ & $\begin{array}{l}\text { Deaths occurring in Taiwan from } 1995 \text { through } \\
2005 \text { were compared with pair matched controls. }\end{array}$ & $\begin{array}{l}\text { Significant association between the levels of air } \\
\text { pollution and bladder cancer mortality (OR, 1.37; } \\
95 \% \text { CI, 1.03-1.82). Statistically significant trend } \\
\text { in the risk of death from bladder cancer with } \\
\text { increasing air pollution level. }\end{array}$ \\
\hline $\begin{array}{l}\text { Yanagi et al. } \\
\text { (2012) [45] }\end{array}$ & $\begin{array}{l}\text { Ecological time } \\
\text { series study }\end{array}$ & $\begin{array}{l}\text { Incidence and mortality for each type of cancer in } \\
\text { the districts with air quality monitoring were } \\
\text { correlated with } \mathrm{PM}_{10} \text { values. }\end{array}$ & $\begin{array}{l}\text { Pearson correlation showed high incidence rates } \\
\text { for bladder cancer with } \mathrm{PM}_{10} \text {. }\end{array}$ \\
\hline $\begin{array}{l}\text { Smith et al. } \\
\text { (2016) [48] }\end{array}$ & $\begin{array}{l}\text { Population-based } \\
\text { cohorts }\end{array}$ & $\begin{array}{l}\text { National Cancer Institute age-adjusted, } \\
\text { county-level bladder cancer mortality data from } \\
1950 \text { to } 2007 \text { were analyzed. }\end{array}$ & $\begin{array}{l}\text { Smoking, unemployment, physically unhealthy } \\
\text { days, air pollution ozone days, percent of houses } \\
\text { with well water, employment in the mining } \\
\text { industry, and urban residences were associated } \\
\text { with increased rates of bladder cancer }\end{array}$ \\
\hline $\begin{array}{l}\text { Pedersen et al. } \\
\text { (2016) [23] }\end{array}$ & $\begin{array}{l}\text { Population-based } \\
\text { cohorts }\end{array}$ & $\begin{array}{l}\text { Fifteen population-based cohorts enrolled } \\
\text { between } 1985 \text { and } 2005 \text { in eight European } \\
\text { countries ( } n=303,431 \text {; mean follow-up } 14.1 \text { years) }\end{array}$ & $\begin{array}{l}\text { None of the exposures }\left(\mathrm{PM}_{2.5}, \mathrm{PM}_{10} \text {, and }\right. \\
\text { nitrogen oxides) were associated with bladder } \\
\text { cancer. }\end{array}$ \\
\hline $\begin{array}{l}\text { Yeh et al. } \\
\text { (2017) [22] }\end{array}$ & $\begin{array}{l}\text { Population-based } \\
\text { cohort }\end{array}$ & Geographically weighted regression was applied & $\begin{array}{l}\text { Ambient } \mathrm{PM}_{2.5} \text { showed a positive correlation with } \\
\text { bladder cancer mortality in males in northern } \\
\text { Taiwan and females in most of the townships in } \\
\text { Taiwan. }\end{array}$ \\
\hline
\end{tabular}

PM, particulate matter; OR, odds ratio; $\mathrm{CI}$, confidence interval.

an ecologic design, the positive associations reported in this study have limited value.

Parent et al. [26] conducted a case-control study to investigate the association between air pollution and prostate cancer using ground-level nitrogen dioxide $\left(\mathrm{NO}_{2}\right)$ as a marker of traffic-related air pollution. They found that exposure to ambient concentrations of $\mathrm{NO}_{2}$ was associated with an increased risk of prostate cancer.

Ramis et al. [25] presented research into the spatial distribution of prostate cancer mortality in an industrialized area. They used distances from each of a number of industrial facilities as an indirect measure of industrial pollution. They found a significantly elevated risk of prostate cancer (by a factor of approximately 1.4) in the immediate vicinity, decaying with distance to a value of 1.08 at $12 \mathrm{~km}$.

Few studies have reported that prostatic hyperplasia was positively related with air pollution [49]; well-designed research will be necessary in the future to address this issue.

\section{CONCLUSIONS}

Too few studies on the association between PM and urologic disease have been conducted to draw conclusions regarding the causal relationship. Research on PM and human health has expanded widely from the cardiorespiratory system to include respiratory cancers and perinatal and reproductive outcomes. The most widely acknowledged mechanism through which PM affects the cardiorespiratory system is by damaging the vascular system, such as causing endothelial injuries to vessels in various organs. PM has been hypothesized to affect the kidney as a secondary effect of its damage to the respiratory or circulatory system. According to this hypothesis, PM-related vessel injury results in hypertension, which must be reflected in the renal tissue. Studies of PM exposure and the circulatory system conducted since 2008 have suggested that renal function may be an early index of cardiovascular disorders due to PM. Since then, the glomerular filtration rate has been used as a useful index to measure early renal functional changes in unhealthy, vulnerable 
populations. Considering the high vascularity of this organ, more research into the direct relationship between PM and chronic renal disease has been conducted since 2016. Two studies reported a significant association between PM exposure and chronic renal disease. However, the relationship between renal cancer and PM is controversial. Although some recently published studies have shown a significant association, these findings are insufficient to demonstrate the quality and quantity of the association. The evidence regarding the potential associations between bladder and prostate cancer likewise does not allow firm conclusions to be drawn. Further well-designed studies on specific urologic diseases are required.

\section{REFERENCES}

1. Boyd JT. Climate, air pollution, and mortality. Br J Prev Soc Med 1960;14:123-35.

2. Davis DL, Bell ML, Fletcher T. A look back at the London smog of 1952 and the half century since. Environ Health Perspect 2002;110: A734-5.

3. Cadelis G, Tourres R, Molinie J. Short-term effects of the particulate pollutants contained in Saharan dust on the visits of children to the emergency department due to asthmatic conditions in Guadeloupe (French Archipelago of the Caribbean). PLoS One 2014;9:e91136.

4. Fang Y, Naik V, Horowitz LW, Mauzerall DL. Air pollution and associated human mortality: the role of air pollutant emissions, climate change and methane concentration increases from the preindustrial period to present. Atmos Chem Phys 2013;13:1377-94.

5. Kim KH, Kabir E, Kabir S. A review on the human health impact of airborne particulate matter. Environ Int 2015;74:136-43.

6. Hamra GB, Guha N, Cohen A, Laden F, Raaschou-Nielsen O, Samet JM, et al. Outdoor particulate matter exposure and lung cancer: a systematic review and meta-analysis. Environ Health Perspect 2014;122:906-11.

7. Kim HC, Kim S, Kim BU, Jin CS, Hong S, Park R, et al. Recent increase of surface particulate matter concentrations in the Seoul Metropolitan Area, Korea. Sci Rep 2017;7:4710.

8. Jo EJ, Lee WS, Jo HY, Kim CH, Eom JS, Mok JH, et al. Effects of particulate matter on respiratory disease and the impact of meteorological factors in Busan, Korea. Respir Med 2017;124:79-87.

9. Han C, Lim YH, Jung K, Hong YC. Association between ambient particulate matter and disorders of vestibular function. Environ Res 2017;155:242-8.

10. Kim H, Kim H, Park YH, Lee JT. Assessment of temporal variation for the risk of particulate matters on asthma hospitalization. Envi- ron Res 2017;156:542-50.

11. Sohn J, You SC, Cho J, Choi YJ, Joung B, Kim C. Susceptibility to ambient particulate matter on emergency care utilization for ischemic heart disease in Seoul, Korea. Environ Sci Pollut Res Int 2016;23:19432-9.

12. Finn WF. Renal response to environmental toxins. Environ Health Perspect 1977;20:15-26.

13. International Labour Organization. Encyclopedia of Occupational Health and Safety [Internet]. Geneva (Switzerland): International Labour Organization; 2012. Chapter 8, Renal-urinary system [cited 2017 Jul 31]. Available from: http://www.ilocis.org/documents/chpt8e.htm.

14. Pesch B, Haerting J, Ranft U, Klimpel A, Oelschlägel B, Schill W. Occupational risk factors for renal cell carcinoma: agent-specific results from a case-control study in Germany. MURC Study Group. Multicenter urothelial and renal cancer study. Int J Epidemiol 2000;29:1014-24.

15. O'Neill MS, Diez-Roux AV, Auchincloss AH, Franklin TG, Jacobs DR Jr, Astor BC, et al. Airborne particulate matter exposure and urinary albumin excretion: the Multi-Ethnic Study of Atherosclerosis. Occup Environ Med 2008;65:534-40.

16. Lue SH, Wellenius GA, Wilker EH, Mostofsky E, Mittleman MA. Residential proximity to major roadways and renal function. J Epidemiol Community Health 2013;67:629-34.

17. Mehta AJ, Zanobetti A, Bind MA, Kloog I, Koutrakis P, Sparrow D, et al. Long-term exposure to ambient fine particulate matter and renal function in older men: The Veterans Administration Normative Aging Study. Environ Health Perspect 2016;124:1353-60.

18. Xu X, Wang G, Chen N, Lu T, Nie S, Xu G, et al. Long-term exposure to air pollution and increased risk of membranous nephropathy in China. J Am Soc Nephrol 2016;27:3739-46.

19. Yang YR, Chen YM, Chen SY, Chan CC. Associations between long-term particulate matter exposure and adult renal function in the Taipei metropolis. Environ Health Perspect 2017;125:602-7.

20. Raaschou-Nielsen O, Pedersen M, Stafoggia M, Weinmayr G, Andersen ZJ, Galassi C, et al. Outdoor air pollution and risk for kidney parenchyma cancer in 14 European cohorts. Int J Cancer 2017; 140:1528-37.

21. Raaschou-Nielsen O, Andersen ZJ, Hvidberg M, Jensen SS, Ketzel M, Sørensen M, et al. Air pollution from traffic and cancer incidence: a Danish cohort study. Environ Health 2011;10:67.

22. Yeh HL, Hsu SW, Chang YC, Chan TC, Tsou HC, Chang YC, et al. Spatial analysis of ambient PM2.5 exposure and bladder cancer mortality in Taiwan. Int J Environ Res Public Health 2017 May 10; 14(5). pii: E508. https://doi.org/10.3390/ijerph14050508.

23. Pedersen M, Stafoggia M, Weinmayr G, Andersen ZJ, Galassi C, 
Sommar J, et al. Is there an association between ambient air pollution and bladder cancer incidence? Analysis of 15 European Cohorts. Eur Urol Focus 2016 Nov 26 [Epub]. pii: S2405-4569(16)30166-3. http:// doi.org/10.1016/j.euf.2016.11.008.

24. Winkelstein W Jr, Kantor S. Prostatic cancer: relationship to suspended particulate air pollution. Am J Public Health Nations Health 1969;59:1134-8.

25. Ramis R, Diggle P, Cambra K, López-Abente G. Prostate cancer and industrial pollution Risk around putative focus in a multisource scenario. Environ Int 2011;37:577-85.

26. Parent MÉ, Goldberg MS, Crouse DL, Ross NA, Chen H, Valois MF, et al. Traffic-related air pollution and prostate cancer risk: a case-control study in Montreal, Canada. Occup Environ Med 2013; 70:511-8.

27. Rim KT, Song SW, Kim HY. Oxidative DNA damage from nanoparticle exposure and its application to workers' health: a literature review. Saf Health Work 2013;4:177-86.

28. Esworthy R. Air Quality: EPA's 2013 Changes to the Particulate Matter (PM) Standard. CRS report No. R42934 [Internet]. Washington, DC: Library of Congress, Congressional Research Service; 2015 Dec 23 [cited 2017 Jul 31]. Available from: https:/fas.org/sgp/ crs/misc/R42934.pdf.

29. Valavanidis A, Fiotakis K, Vlachogianni T. Airborne particulate matter and human health: toxicological assessment and importance of size and composition of particles for oxidative damage and carcinogenic mechanisms. J Environ Sci Health C Environ Carcinog Ecotoxicol Rev 2008;26:339-62.

30. Brokamp C, Jandarov R, Rao MB, Grace L, Ryan P. Exposure assessment models for elemental components of particulate matter in an urban environment: A comparison of regression and random forest approaches. Atmos Environ 2017;151:1-11.

31. Qin X, Liang J, Zhang L, Wu Y, Liu X. MP357Long-term exposure to air pollutants and mortality in patients with renal replacement therapy: a systematic review. Nephrol Dial Transplant 2017;32(Suppl 3):iii558.

32. US Environmental Protection Agency. Particulate matter (PM) basics [Internet]. Washington, DC: US Environmental Protection Agency; 2016 [cited 2017 Jul 31]. Available from: https://www.epa. gov/pm-pollution/particulate-matter-pm-basics.

33. Lee N, Lee BK, Jeong S, Yi GY, Shin J. Work environments and exposure to hazardous substances in korean tire manufacturing. Saf Health Work 2012;3:130-9.

34. Cheung K, Daher N, Kam W, Shafer MM, Ning Z, Schauer JJ, et al. Spatial and temporal variation of chemical composition and mass closure of ambient coarse particulate matter (PM10-2.5) in the Los
Angeles area. Atmos Environ 2011;45:2651-62.

35. Madureira J, Paciência I, Fernandes Ede O. Levels and indoor-outdoor relationships of size-specific particulate matter in naturally ventilated Portuguese schools. J Toxicol Environ Health A 2012;75: 1423-36.

36. Aust AE, Ball JC, Hu AA, Lighty JS, Smith KR, Straccia AM, et al. Particle characteristics responsible for effects on human lung epithelial cells. Res Rep Health Eff Inst 2002;(110):1-65.

37. Araujo JA. Particulate air pollution, systemic oxidative stress, inflammation, and atherosclerosis. Air Qual Atmos Health 2010;4:79-93.

38. Soderland P, Lovekar S, Weiner DE, Brooks DR, Kaufman JS. Chronic kidney disease associated with environmental toxins and exposures. Adv Chronic Kidney Dis 2010;17:254-64.

39. Shah SV, Baliga R, Rajapurkar M, Fonseca VA. Oxidants in chronic kidney disease. J Am Soc Nephrol 2007;18:16-28.

40. Möhner M, Pohrt A, Gellissen J. Occupational exposure to respirable crystalline silica and chronic non-malignant renal disease: systematic review and meta-analysis. Int Arch Occup Environ Health 2017 Apr 13 [Epub]. http://doi.org/10.1007/s00420-017-1219-X.

41. Rastogi SK. Renal effects of environmental and occupational lead exposure. Indian J Occup Environ Med 2008;12:103-6.

42. Zheng L, Kuo CC, Fadrowski J, Agnew J, Weaver VM, Navas-Acien A. Arsenic and chronic kidney disease: a systematic review. Curr Environ Health Rep 2014;1:192-207.

43. Harrison RM, Yin J. Particulate matter in the atmosphere: which particle properties are important for its effects on health? Sci Total Environ 2000;249:85-101.

44. Chow WH, Dong LM, Devesa SS. Epidemiology and risk factors for kidney cancer. Nat Rev Urol 2010;7:245-57.

45. Yanagi Y, Assunção JV, Barrozo LV. The impact of atmospheric particulate matter on cancer incidence and mortality in the city of São Paulo, Brazil. Cad Saude Publica 2012;28:1737-48.

46. Castaño-Vinyals G, Cantor KP, Malats N, Tardon A, Garcia-Closas $\mathrm{R}$, Serra $\mathrm{C}$, et al. Air pollution and risk of urinary bladder cancer in a case-control study in Spain. Occup Environ Med 2008;65:56-60.

47. Liu CC, Tsai SS, Chiu HF, Wu TN, Chen CC, Yang CY. Ambient exposure to criteria air pollutants and risk of death from bladder cancer in Taiwan. Inhal Toxicol 2009;21:48-54.

48. Smith ND, Prasad SM, Patel AR, Weiner AB, Pariser JJ, Razmaria A, et al. Bladder cancer mortality in the United States: a geographic and temporal analysis of socioeconomic and environmental factors. J Urol 2016;195:290-6.

49. Shim SR, Kim JH, Song YS, Lee WJ. Association between air pollution and benign prostatic hyperplasia: An ecological study. Arch Environ Occup 